\title{
PENGEMBANGAN INSTRUMEN EVALUASI SOAL PILIHAN GANDA BERBASIS HOT POTATOES PADA MATA KULIAH STATISTIK
}

\author{
Iesyah Rodliyah $^{1}$, Sari Saraswati ${ }^{2}$ \\ ${ }^{1,2}$ Program Studi Pendidikan Matematika, Universitas Hasyim Asy'ari Tebuireng Jombang \\ Email: iesyahrodliyah90@gmail.com
}

\begin{abstract}
Abstrak:
Penelitian ini bertujuan untuk mendeskripsikan setiap tahapan pengembangan instrument tes evaluasi hasil belajar statistik yang dikemas menggunakan aplikasi media evaluasi pembelajaran berbasis IT yaitu Hot Potatoes. Model pengembangan yang digunakan pada penelitian ini adalah model ADDIE yang terdiri dari lima tahapan, yaitu (1) analysis, (2) design, (3) development, (4) implementation, dan (5) evaluation. Subyek uji coba pada penelitian pengembangan ini antara lain ahli materi, ahli media, dan mahasiswa pendidikan matematika yang mengampu mata kuliah statistik.Data penelitian dikumpulkan melalui tes dan angket. Data penelitian dianalisis menggunakan teknik analisis deskriptif. Produk penelitian yang dihasilkan berupa instrument tes soal berupa soal pilihan ganda menggunakan media evaluasi pembelajaran berbasis $\mathrm{Hot}$ Potatoes. Hasil analisis menunjukkan bahwa produk berupa instrument soal tes statistik berbasis hot potatoes dinyatakan layak untuk digunakan dalam mengevaluasi hasil belajar mahasiswa serta.memenuhi kriteria valid, praktis, dan efektif.
\end{abstract}

Kata Kunci: Instrumen Tes, Evaluasi Hasil Belajar, Statistik, Hot Potatoes

\begin{abstract}
:
This study aims to describe each stage of the development of a statistical learning outcome evaluation test instrument which is packaged using an IT-based learning evaluation media application, namely Hot Potatoes. The development model used in this study is the ADDIE model which consists of five stages, namely (1) analysis, (2) design, (3) development, (4) implementation, and (5) evaluation. The subjects of the trials in this development research included material experts, media experts, and mathematics education students who taught statistics courses. The research data were collected through tests and questionnaires. The research data were analyzed using descriptive analysis techniques. The resulting research product was a test instrument in the form of multiple choice questions using Hot Potatoes based learning evaluation media. The results of the analysis showed that the product in the form of a hot potatobased statistical test question instrument was declared feasible to be used in evaluating student learning outcomes and met the criteria of being valid, practical, and effective.
\end{abstract}

Keywords: Test Instruments, Evaluation of Learning Outcomes, Statistics, Hot Potatoes

\section{Pendahuluan}

Sistem pendidikan yang berada di Negara Indonesia dengan sangat tegas memberi aturan mengenai pentingnya melakukan evaluasi/penilaian terhadap peserta didik. Terlihat pada Peraturan yang dikeluarkan ole Pemerintah RI No 19 Tahun 2005 mengenai Standar Nasional Pendidikan pada Bab I Ketentuan Umum Pasal 1 butir 17 yang telah menyebutkan bahwa penilaian merupakan suatu proses pengumpulan dan pengolahan informasi guna bisa melakukan pengukuran terhadap pencapaian hasil belajar peserta didik. Sasaran disrupsi yang sangat menonjol pada abad ke 21 ini adalah institusi Perguruan Tinggi. Perguruan tinggi yang berada di Indonesia tampak sudah jarang terdengar di Asia. Salah satu penyebabnya adalah kurangnya inovasi dalam segala hal. (Kasali, 2018:21) Inovasi selalu terkait dengan beberapa nilai praktis di dunia. Diantaranya tentang bagaimana membuat alat, produk, atau proses baru, menghasilkan sesuatu yang baru yang memungkinkan manusia untuk mencapai sesuatu yang mereka tidak mampu capai sebelumnya.

Salah satu yang perlu dilakukan inovasi dalam dunia pendidikan khususnya 
di Universitas Hasyim Asy'ari adalah bagaimana cara mengevaluasi hasil belajar mahasiswa. Menurut Mahirah (2017:258) definisi evaluasi umumnya sebagai suatu proses yang sistematis yang digunakan untuk menentukan suatu nilai yang didasarkan pada kriteria/kategori yang berlaku dengan terlebih dahulu melalui penilaian. Ketika akan menentukan nilai sesuatu dilakukan menggunakan cara membandingkan dengan adanya kriteria, sehingga orang yang akan melakukan evaluasi bisa langsung membandingkan dengan kriteria secara umum, bisa juga mengukur terhadap sesuatu hal yang dievaluasi setelah itu membandingkan menggunakan kriteria tertentu. Adapun definisi dari evaluasi belajar dan pembelajaran merupakan suatu proses guna mengukur nilai belajar dan pembelajaran yang telah ditempuh melalui kegiatan penilaian/pengukuran. Keberadaan evaluasi dalam dunia pendidikan mampu mengetahui tingkat keberhasilan dan ketercapaian yang sudah diraih oleh para peserta didik selarna melaksanakan kegiatan belajar mengajar di kelas. Gensee (Jabbarifar, 2009:3) percaya bahwa tujuan lain dari evaluasi adalah untuk membimbing pengajaran di kelas dan meningkatkan pembelajaran peserta didik setiap hari. Gensee juga menambahkan bahwa penilaian dan evaluasi kelas terutama berkaitan dengan peningkatan pengajaran sehingga pembelajaran peserta didik ditingkatkan. Tenaga pendidik dalam sistem pendidikan, lebih dari siapa pun, secara aktif dan terus menerus terlibat dalam penilaian dan evaluasi. Peserta didik juga dapat menjadi peserta aktif dalam menilai prestasi mereka sendiri dan merencanakan bagaimana mereka akan belajar.

Pentingnya adanya evaluasi hasil belajar menjadikan perlunya dilakukan inovasi dalam mengevaluasi hasil belajar mahasiswa di UNHASY khususnya pada mahasiswa pendidikan matematika yang selama ini dilakukan secara tertulis. Evaluasi secara tertulis memiliki beberapa kelemahan salah satunya tidak efesiensi waktu. Terlebih lagi jumlah mahasiswa di UNHASY yang setiap tahunnya alhamdulillah mengalami kenaikan dan peningkatan. Perkembangan zaman yang modern mulai memunculkan aplikasiaplikasi yang bisa digunakan untuk mengevaluasi hasil belajar peserta didik baik siswa/pun mahasiswa. Salah satunya adalah software hot potatoes, aplikasi ini merupakan media interaktif yang bisa digunakan untuk mengevaluasi hasil belajar mahasiswa dan dirasa mampu menekan kelemahan sistem konvensional saat ini. Aplikasi ini merupakan aplikasi pendidikan yang di dalamnya memuat latiha-latihan dengan berbagai tipe (Anggoro \& Arif, 2018:25). Hot Potatoes adalah software yang terdiri dari 6 macam fasilitas yang dapat digunakan untuk membuat soal latihan (quiz) berbasis web interaktif. Kuis yang dibuat, menggunakan Javasript untuk interaktivitasnya, dan kuis ini dapat dibuka dengan browser Mozila Firefox dan Internet Explorer versi 4 ke atas, ataupun jenis browser lain dimana memiliki Javasript sebagai fiturnya. Hot Potatoes juga dapat dijalankan diberbagai Operating System, seperti Windows, Machintos juga Linux. Tiap jenis kuis yang terdapat pada software Hot Potatoes dapat dibuat secara interatif, karena: (1) dapat langsung mengoreksi; (2) memberi nilai; (3) memberi umpan balik berupa penjelasan soal; (4) pembatasan waktu; (5) soal diacak secara random, baik nomor soal maupun jawaban; (6) untuk kuis menjodohkan dapat dibuat model drag and drop, jadi jawaban dapat ditarik dan dipasangkan ke kuis; dan (7) dapat diisi dengan multimedia, seperti gambar, suara, dan video. (Saputri, 2015:89)

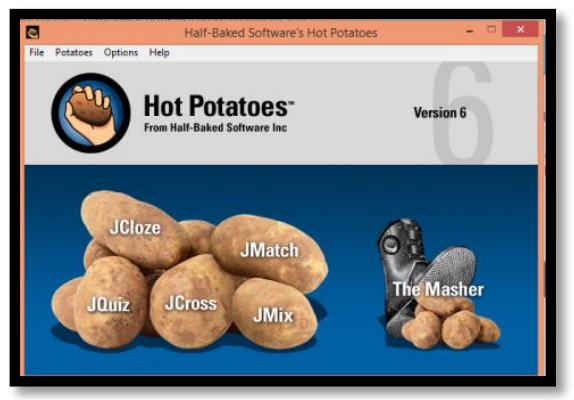

Gambar 1. Tampilan Aplikasi Hot Potatoes 
Software Hot Potatoes digunakan sebagai alat/produk yang mampu mempermudah melakukan evaluasi hasil belajar statistik mahasiswa. Dalam proses pengembangan software diperlukan instrument tes evaluasi hasil belajar.

Sama halnya dengan hasil penelitian yang telah dilakukan oleh Yasa, dkk (2020:26) dengan judul "Pengembangan -Evaluation Berbasis Aplikasi Hot Potatoes untuk Siswa Kelas V Sekolah Dasar." Penelitian ini menjelaskan mengenai proses pengembangan EEvaluation berbasis Aplikasi Hot Potatoes. Hasil penelitian yang telah dilakukan menghasilkan produk e-evaluation berbasis aplikasi Hot Potatoes yang layak, praktis, dan efektif digunakan pada siswa kelas $\mathrm{V}$ SD Kota Malang. Oleh sebab itu, pada penelitian ini peneliti juga turut mengembangkan produk berupa instrument tes evaluasi soal pilihan ganda berbasis $\mathrm{Hot}$ Potatoes dengan sasaran pengguna mahasiswa pada mata kuliah statistik. Pada penggunaan Software Hot Potatoes, peneliti hanya menggunakan JQUIZ saja karena soal yang akan dikembangkan untuk mengukur berpikir kritis mahasiswa berupa soal pilihan ganda berjumlah 20 soal.

\section{Metode Penelitian Jenis Penelitian}

Penelitian ini menggunakan jenis penelitian pengembangan. Model pengembangan yang digunakan pada penelitian ini adalah model ADDIE yaitu penelitian yang diperuntukkan menghasilkan suatu produk tertentu, serta menguji keefektifan produk tersebut (Pribadi, 2009:125). Tahapan penelitian dan pengembangan ditunjukkan pada Gambar 2 .

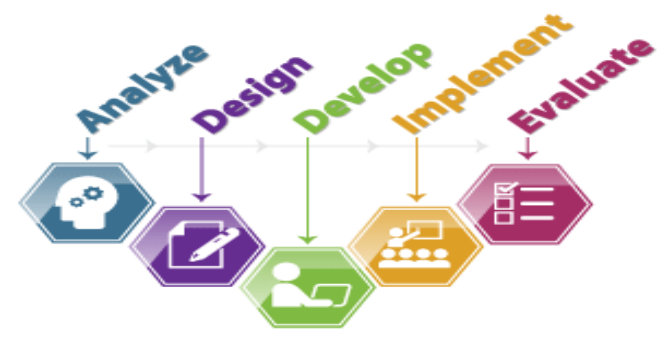

Gambar 2. Tahapan Penelitian dan Pengembangan ADDIE

\section{Subyek Penelitian}

Subyek penelitian ini adalah mahasiswa Pendidikan Matematika Fakultas Ilmu Pendidikan di Universitas Hasyim Asy'ari Tebuireng Jombang yang mengampu mata kuliah ststistik pada tahun akademik 2019/2020. Sedangkan subyek uji coba dalam penelitian ini adalah mahasiswa prodi Pendidikan Bahasa Inggris Fakultas Ilmu Pendidikan Universitas Hasyim Asy'ari.

\section{Teknik dan Alat Pengumpul Data}

Faktor yang diteliti yaitu berupa hasil pengembangan instrument tes evaluasi hasil belajar statistik yang dikemas dalam software hot potatoes, penilaian mahasiswa dan hasil belajar. Data diperoleh dengan metode angket dan tes. Soal yang diujikan sebanyak 20 soal pilihan ganda yang sebelumnya sudah dilakukan uji validasi kepada para pakar yang ahli dalam bidangnya. Tes dalam penelitian ini dilaksanakan secara online. Hal ini dikarenakan terjadinya pandemi covid-19 di Indonesia. Adapun teknik analisis data meliputi uji validitas instrument yang dilakukan oleh ahli media dan ahli materi, uji kepraktisan produk, uji efektifitas produk. Selain itu akan dilakukan uji pada setiap butir tes kepada kelas uji coba, diantaranya uji validitas butir soal, uji reliabilitas soal, dan uji sensitifitas butir soal.

\section{Teknik Analisis Data}

Van den Akker menyatakan bahwa dalam melakukan penelitian pengembangan perlu kriteria kualitas yaitu kevalidan, kepraktisan, dan keefektifan (Rohmad, $2012: 68-71$ ).

1) Analisis Data Validitas Instrumen

Validator menuliskan penilaian pada setiap lembar validasi hasil instrument tes evaluasi yang sudah dikembangkan menggunakan software hot potatoes. Penilaian terdiri dari lima kategori yaitu : tidak baik (nilai 1), kurang baik (nilai 2), cukup baik (nilai 3), baik (nilai 4) dan sangat baik (nilai 5). Analisis validitas instrument dilakukan dengan langkah-langkah : 1) Merekapitulasi data uji validasi dari validator, 2) Mencari rata-rata total skor 
tiap indikator dari semua validator dengan rumus, 3) Instrumen dikatakan valid jika setiap indikator mendapat kategori minimal cukup baik (nilai 3).

2) Analisis Data Kepraktisan Instrumen

Data mengenai kepraktisan produk yang dikembangkan dilihat dari hasil penilaian mahasiswa yang telah menggunakan produk berupa instrumen tes evaluasi hasil belajar statistik yang dikemas dalam software hot potatoes untuk mengetahui kemampuan berpikir kritis mahasiswa. Secara umum, analisis dari data tersebut dilakukan dengan cara mengelompokkan data kemudian melakukan perhitungan rata-rata setiap aspek dan rata-rata total.

3) Analisis Data Keefektifan Instrumen

Keefektifan Produk dilihat dari data hasil tes belajar mahasiswa. Seorang mahasiswa dikatakan tuntas belajar apabila mahasiswa telah memperoleh nilai minimal 70 . Sedangkan ketuntasan belajar secara klasikal tercapai apabila paling sedikit $75 \%$ dari jumlah seluruh mahasiswa telah tuntas belajar. Analisis butir tes dilakukan untuk mendapatkan masukan dalam merevisi tes :

a. Validitas

Suatu tes dikatakan valid apabiala tes tersebut mengukur kemampuan siswa pada pembelajaran sesuai dengan tujuan yang telah ditetapkan. Arikunto (2011:76) menyatakan sebuah tes dikatakan memiliki validitas tinggi jika skor pada butir soal memiliki kesejajaran dengan skor total. Kesejajaran ini dapat diartikan dengan kolerasi sehingga untuk mengetahui validitas butir digunakan rumus kolerasi product moment. (Hobri, 2010:49).

validitas butir digunakan rumus kolerasi product moment berikut:

$$
\begin{aligned}
& r_{x y}= \frac{n \sum_{i=1}^{n} X_{i} Y_{i}-\left(\sum_{i=1}^{n} X_{i}\right)\left(\sum_{i=1}^{n} Y_{i}\right)}{\sqrt{\left(n \sum_{i=1}^{n} X_{i}^{2}-\left(\sum_{i=1}^{n} X_{i}\right)^{2}\right)\left(n \sum_{i=1}^{n} Y_{i}^{2}-\left(\sum_{i=1}^{n} Y_{i}\right)^{2}\right)}} \\
& \text { Keterangan : } \\
& \mathrm{X}=\text { Skor butir } \\
& \mathrm{Y}=\text { Skor total }
\end{aligned}
$$

$r_{x y}=$ Koefisien korelasi skor butir dan skor total

$\mathrm{N}$ = Banyaknya siswa yang mengikuti tes

Koefisien korelasi diinterpretasikan pada tabel berikut :

\section{Tabel 2. Koefisien Korelasi}

\begin{tabular}{cc}
\hline Koefisien Korelasi & Interpretasi \\
\hline $0.80<\boldsymbol{r}_{x y} \leq 1.00$ & $\begin{array}{c}\text { Validitas butir tes } \\
\text { sangat tinggi } \\
\text { Validitas butir tes } \\
\text { tinggi }\end{array}$ \\
$0.60<\boldsymbol{r}_{x y} \leq 0.80$ & $\begin{array}{c}\text { Validitas butir tes } \\
\text { cukup } \\
0.40\end{array}$ \\
$0.00<\boldsymbol{r}_{x y} \leq 0.40$ & $\begin{array}{c}\text { Validitas butir tes } \\
\text { rendah }\end{array}$ \\
& $\begin{array}{c}\text { Validitas butir tes } \\
\text { sangat rendah }\end{array}$ \\
\hline
\end{tabular}

b. Reliabilitas

Reliabilitas tes dihitung untuk mengetahui konsistensi hasil tes. Koefisien realibitas suatu tes dapat diukur dengan menggunakan rumus alpha (Arikunto,2011:109) sebagai berikut:

$$
r_{11}(\alpha)=\left(\frac{n}{(n-1)}\right)\left(1-\frac{\sum \sigma_{i}^{2}}{\sigma_{i}^{2}}\right)
$$

Keterangan :

$r_{11}=$ reliabilitas

$\sum \sigma_{i}^{2}=$ jumlah varians tiap-tiap

item

$\sigma_{i}^{2}=$ varians total

$\mathrm{n} \quad=$ banyaknya soal

Reliabilitas diinterpretasikan pada tabel berikut :

Tabel 3. Koefisien Reliabilitas

\begin{tabular}{cl}
\hline \multicolumn{1}{c}{ Reliabilitas } & Interpretasi \\
\hline $0.80<\boldsymbol{r}_{\mathbf{1 1}} \leq 1.00$ & $\begin{array}{l}\text { Reliabilitas } \\
\text { sangat tinggi }\end{array}$ \\
$0.60<\boldsymbol{r}_{\mathbf{1 1}} \leq 0.80$ & $\begin{array}{l}\text { Reliabilitas } \\
\text { tinggi }\end{array}$ \\
$0.40<\boldsymbol{r}_{\mathbf{1 1}} \leq 0.60$ & $\begin{array}{l}\text { Reliabilitas } \\
\text { cukup }\end{array}$ \\
$0.20<\boldsymbol{r}_{\mathbf{1 1}} \leq 0.40$ & $\begin{array}{l}\text { Reliabilitas } \\
\text { rendah } \\
\text { Reliabilitas } \\
\text { sangat rendah }\end{array}$ \\
$\boldsymbol{r}_{\mathbf{1 1}} \leq 0,20$ &
\end{tabular}

Guilford (dalam Hobri, 2010:47) 
Dalam penelitian ini, tes dinyatakan reliabel jika koefsien reliabilitas tes tersebut diinterpretasikan minimal cukup.

\section{c. Sensitivitas}

Sensitivitas merupakan ukuran seberapa baik butir soal itu dapat membedakan tingkat kemampuan siswa sebelum menerima pembelajaran dan sesudah menerima pembelajaran. Sensitivitas butir menggunakan rumus sebagai berikut :

$$
S=\frac{\sum S_{e s}-\sum S_{e b}}{N\left(\text { Skor }_{\text {max }}-\text { Skor }_{\text {min }}\right)}
$$

(Grounlund, 1982:106)

Keterangan :

$\mathrm{S}=$ Indeks sensitivitas butir soal

$\mathrm{N}$ = Banyaknya siswa

$\sum S_{e s}=$ Jumlah skor subjek sesudah proses pembelajaran

$\sum S_{e b}=$ Jumlah skor subjek sebelum proses pembelajaran

Skor ${ }_{\text {max }}=$ Skor maksimum yang dapat dicapai oleh subjek

Skor $_{\text {min }}=$ Skor minimum yang dapat dicapai oleh subjek

Nilai sensitivitas butir tes berkisar antara -1.00 sampai 1.00. Butir tes dikatakan baik apabila koefisien sensitivitasnya berkisar antara 0 dan 1 . Suatu butir tes dikatakan peka (sensitif) terhadap pembelajaran jika $S \geq 0,30$.

Sensitivitas merupakan ukuran seberapa baik butir soal itu dapat membedakan tingkat kemampuan mahasiswa sebelum menerima pembelajaran dan sesudah menerima pembelajaran.

\section{Hasil dan Pembahasan \\ Analisis (Analysis)}

Berdasarkan hasil observasi yang telah dilakukan sebelumnya tepatnya bulan Agustus 2019. Masih banyak perguruan tinggi yang menggunakan cara konvensional dalam mengevaluasi hasil belajar mahasiswa khususnya pada prodi pendidikan matematika di Universitas Hasyim Asy'ari. Sehingga perlu dilakukan inovasi bagaimana cara mengevaluasi hasil belajar mahasiswa yang praktis dan efektif serta bisa dilakukan secara online terlebih lagi dengan kondisi Indonesia yang saat ini dilanda musibah pandemi covid 19. Evaluasi secara tertulis memiliki kelemahan salah satunya tidak efesiensi waktu. Pada era society 5.0 ini memunculkan aplikasi-aplikasi yang bisa digunakan untuk mengevaluasi hasil belajar peserta didik baik siswa/pun mahasiswa. Salah satunya adalah software hot potatoes, aplikasi ini merupakan media interaktif yang bisa digunakan untuk mengevaluasi hasil belajar mahasiswa dan dirasa mampu menekan kelemahan sistem konvensional saat ini. Sehingga pada penelitian ini, peneliti akan mengembangankan alat evaluasi pembelajaran menggunakan aplikasi hot potatoes pada mata kuliah statistik

\section{Perancangan (Design)}

Rancangan pembuatan tes evaluasi menggunakan aplikasi hot potatoes didasarkan pada RPS statistik yang sudah dibuat peneliti. soal yang akan diujikan menggunakan software tersebut mencakup Tiga materi yaitu : Pengujian mean dua populasi untuk sampel-sampel bebas dan berkorelasi pada suatu masalah kontekstual, Teori dan aplikasi tentang analisis korelasi, tujuan analisis korelasi, serta teori dan aplikasi dari analisis regresi.

Soal pada aplikasi hot potatoes hanya menggunakan menu JQUIZ, karena soal yang dibuat adalah soal-soal pilihan ganda. Soal dibuat hanya bisa dikerjakan sebanyak satu kali oleh setiap satu mahasiswa dan tidak bisa diulang kembali. Hasil tes yang telah dikerjakan mahasiswa akan tampak diakhir setelah mahasiswa menyelesaikan seluruh soal yang diberikan.

\section{Pengembangan (Develop)}

Pada tahap ini dilakukan proses pengembangan instrument tes evaluasi berupa soal-soal pilihan ganda menggunakan aplikasi hot potatoes dengan menu JQUIZ. 


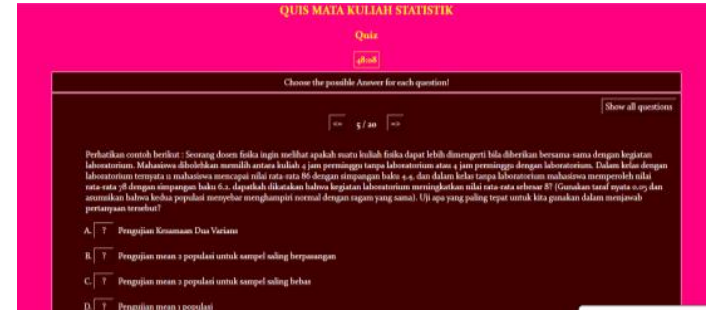

Gambar 3. Tampilan Instrument Tes Menggunakan Hot Potatoes

Setelah selesai mengembangnkan instrument tes evaluasi menggunakan aplikasi hot potatoes. Maka langkah selanjutnya adalah melakukan Validasi materi dan media kepada para pakar yang ahli di bidangnya. Pada penelitian ini, peneliti mengambil 2 validator, masingmasing 1 validator ahli media, dan 1 validator ahli materi.

\section{Analisis Data Kevalidan Instrumen}

Berdasarkan hasil validasi dari ahli media dan materi dapat diketahui kelayakan instrumen tes evaluasi hasil belajar statistik yang dikemas dalam software hot potatoes. Hasil validasi instrumen dapat dilihat pada Tabel berikut :

\section{Hasil Validasi Ahli Media}

Tabel 4. Hasil Penilaian Validator Ahli Media

\begin{tabular}{|c|c|c|c|c|}
\hline Aspek & $\begin{array}{l}\text { Penilaian } \\
\text { Validator }\end{array}$ & $\begin{array}{l}\text { Nilai } \\
\text { Maks }\end{array}$ & $\begin{array}{l}\text { Rata- } \\
\text { rata }\end{array}$ & Kategori \\
\hline Umum & 17 & 20 & 4.25 & Baik \\
\hline $\begin{array}{l}\text { Rekayasa } \\
\text { Perangkat } \\
\text { Lunak }\end{array}$ & 14 & 15 & 4.67 & Baik \\
\hline $\begin{array}{l}\text { Komunika } \\
\text { si Visual }\end{array}$ & 24 & 30 & 4 & Baik \\
\hline $\begin{array}{l}\text { Desain } \\
\text { Media }\end{array}$ & 33 & 35 & 4.71 & Baik \\
\hline \multicolumn{3}{|c|}{$\begin{array}{c}\text { Rata-Rata Total } \\
\text { Kelayakan }\end{array}$} & \multicolumn{2}{|c|}{$\begin{array}{c}\text { Layak digunakan } \\
\text { dengan revisi kecil }\end{array}$} \\
\hline
\end{tabular}

\footnotetext{
Berdasarkan Tabel 4 dapat disimpulkan bahwa produk yang dikembangkan berdasarkan penilaian Ahli Media dikatakan valid. Hal ini dikarenakan penilaian yang diberikan oleh validator ahli media menunjukkan rata-rata total sebesar 4,4075 yang artinya produk berada pada kategori baik.
}

\section{Hasil Validasi Ahli Materi}

\section{Tabel 5. Hasil Penilaian Validator Ahli} Materi

\begin{tabular}{|c|c|c|c|c|}
\hline Aspek & $\begin{array}{l}\text { Penilaian } \\
\text { Validator }\end{array}$ & $\begin{array}{l}\text { Nilai } \\
\text { Maks }\end{array}$ & $\begin{array}{l}\text { Rata- } \\
\text { Rata }\end{array}$ & Kategor \\
\hline Format & 10 & 10 & 5 & $\begin{array}{l}\text { Sangat } \\
\text { Baik }\end{array}$ \\
\hline Isi & 17 & 20 & 4.25 & Baik \\
\hline Bahasa & 32 & 35 & 4.57 & Baik \\
\hline \multicolumn{3}{|c|}{$\begin{array}{c}\text { Rata-Rata Total } \\
\text { Kelayakan }\end{array}$} & $\begin{array}{r}4,606 \\
\text { Layak } \\
\text { dengan }\end{array}$ & $\begin{array}{l}\text { Baik } \\
\text { igunakan } \\
\text { evisi kecil }\end{array}$ \\
\hline
\end{tabular}

$\begin{array}{rrrr}\text { Berdasarkan } & \text { Tabel } 5 & \text { dapat } \\ \text { disimpulkan bahwa } & \text { produk } & \text { yang }\end{array}$
dikembangkan berdasarkan penilaian ahli materi dikatakan valid. Hal ini dikarenakan penilaian yang diberikan oleh validatr ahli materi menunjukkan rata-rata total sebesar 4,606 yang artinya produk berada pada kategori baik.

Berdasarkan penilaian dari validtor ahli media dan ahli materi dapat diketahui bahwa penilaian validator secara keseluruhan adalah valid. Instrumen tes evaluasi hasil belajar statistik yang dikemas dalam software hot potatoes siap digunakan setelah dilakukan beberapa revisi berdasarkan komentar dan saran perbaikan dari validator.

\section{Implementasi (Implementation)}

Pada tahap ini dilakukan uji coba kelas terbatas dan uji coba kelas utama. Uji coba kelas terbatas dilakukan untuk menguji analisis butir tes yang sudah dibuat. Pada saat uji coba kelas terbatas, peneliti memberikan soal-soal pilihan ganda sebanyak 26 soal yang nantinya akan dilakukan uji validitas, reliabilitas, dan sensitivitas. Pelaksanaan Uji coba terbatas dilaksanakan pada tanggal 14 April 2020 pada mahasiswa program studi pendidikan Bahasa Inggris. Dari hasil uji coba kelas terbatas, 26 soal yang disediakan dan diujikan menggunakan uji validitas, hanya 20 soal saja yang dinyatakan valid. Sehingga untuk uji reliabilitas dan sensitivitas dilihat dari 20 soal yang sudah terbukti valid saja. 


\section{Analisis Butir Soal Tes pada Instrumen Validitas}

Perhitungan validitas setiap butir tes menggunakan rumus korelasi product moment. Dari 26 soal yang diberikan kepada mahasiswa di kelas uji coba, Ada 20 soal yang dinyatakan valid dan cukup valid, 6 diantaranya dinyatakan tidak valid. Sehingga soal yang digunakan pada kelas utama hanya 20 soal pilihan ganda saja. Berikut ini adalah tabel hasil perhitungan validitas setiap butir soal yang dinyatakan valid :

Tabel 6. Nilai Validitas Tiap Butir Tes yang Dinyatakan Valid

\begin{tabular}{ccc}
\hline No. Soal & $\boldsymbol{r}_{\boldsymbol{x} y}$ & Kriteria \\
\hline 1 & 0.964 & Sangat Tinggi \\
2 & 0.964 & Sangat Tinggi \\
3 & 0.740 & Tinggi \\
4 & 0.740 & Tinggi \\
5 & 0.740 & Tinggi \\
6 & 0.773 & Tinggi \\
7 & 0.599 & Cukup Tinggi \\
8 & 0.773 & Tinggi \\
9 & 0.571 & Cukup Tinggi \\
10 & 0.599 & Cukup Tinggi \\
11 & 0.964 & Sangat Tinggi \\
12 & 0.541 & Cukup Tinggi \\
13 & 0.773 & Tinggi \\
14 & 0.541 & Cukup Tinggi \\
15 & 0.964 & Sangat Tinggi \\
16 & 0.773 & Tinggi \\
17 & 0.571 & Cukup Tinggi \\
18 & 0.541 & Cukup Tinggi \\
19 & 0.964 & Sangat Tinggi \\
20 & 0.740 & Tinggi \\
\hline
\end{tabular}

\section{Reliabilitas}

Dari hasil perhitungan reliabilitas menggunakan SPSS terhadap 20 soal yang dinyatakan valid, diperoleh koefisien reliabilitas tes $\alpha=0,490$. Artinya tes hasil belajar cukup reliabel untuk mengukur kemampuan berpikir kritis mahasiswa terhadap mata kuliah statistik.

\section{Sensitifitas}

Berdasarkan rumus sensitivitas terhadap 20 soal yang dinyatakan valid diperoleh nilai sensitivitas setiap butir tes sebagai berikut :

Tabel 7. Nilai Sensitifitas Tiap Butir Tes

\begin{tabular}{ccc}
\hline No. Soal & $\boldsymbol{r}_{\boldsymbol{x y}}$ & Kriteria \\
\hline 1 & 0,315 & Sensitif \\
2 & 0,78 & Sensitif \\
3 & 0,368 & Sensitif \\
4 & 0,42 & Sensitif \\
5 & 0,84 & Sensitif \\
6 & 0,368 & Sensitif \\
7 & 0,42 & Sensitif \\
8 & 0,68 & Sensitif \\
9 & 0,63 & Sensitif \\
10 & 0,52 & Sensitif \\
11 & 0,47 & Sensitif \\
12 & 0,63 & Sensitif \\
13 & 0,63 & Sensitif \\
14 & 0,84 & Sensitif \\
15 & 0,736 & Sensitif \\
16 & 0,736 & Sensitif \\
17 & 0,421 & Sensitif \\
18 & 0,368 & Sensitif \\
19 & 0,368 & Sensitif \\
20 & 0,368 & Sensitif \\
\hline
\end{tabular}

Dari hasil yang ada pada Tabel 7 tampak bahwa setiap butir tes peka terhadap pembelajaran. Oleh karena itu, setiap butir tes hasil belajar dianggap layak untuk digunakan untuk mengukur kemampuan berpikir kritis mahasiswa pada kelas uji utama.

Setelah dilakukan analisis butir tes, maka instrumen tes yang dikembangkan dengan menggunakan aplikasi hot potatoes siap diimplementasikan pada kelas utama. Adapun pelaksanaannya dilakukan pada tanggal 22 April 2020 secara online.

\section{Evaluasi (Evaluation)}

Pada tahap evaluasi ini digunakan untuk mengevaluasi hasil produk yang sudah dikembangkan dan diujicobakan. Masukan dan saran dari pengguna produk dilakukan untuk perbaikan produk. Masukan yang diberikan oleh pengguna produk diantaranya adalah ada beberapa kata yang salah ketik sehingga harus dibenarkan. Selain dilakukan uji kevaliditas produk, juga dilakukan analisis kepraktisan 
dan keefektifan yang dilakukan setelah produk diujicobakan pada kelas utama.

\section{Analisis Data Kepraktisan Instrumen}

Kepraktisan tes evaluasi hasil belajar statistik yang dikemas dalam software hot potatoes pada penelitian ini didasarkan pada data hasil penilaian mahasiswa setelah menggunakan produk.

\section{Hasil Penilaian Mahasiswa}

Hasil penilaian mahasiswa yang dilaksanakan pada subyek uji coba utama yaitu mahasiswa pendidikan matematika yang menempuh mata kuliah statistik sebanyak 19 mahasiswa. Setelah diuji cobakan, para mahasiswa diminta untuk memberikan penilaian terkait produk yang sudah dikembangkan. Berikut hasil penilaian mahasiswa setelah menggunakan produk :

Tabel 8. Hasil Penilaian Mahasiswa

\begin{tabular}{lcc}
\hline \multicolumn{1}{c}{ Aspek } & $\begin{array}{c}\text { Persentase } \\
\text { Respon } \\
\text { Positif }\end{array}$ & $\begin{array}{c}\text { Persentase } \\
\text { Respon } \\
\text { Negatif }\end{array}$ \\
\hline $\begin{array}{l}\text { Respon pengguna } \\
\text { terhadap software } \\
\text { Respon pengguna } \\
\text { terhadap alat } \\
\text { evaluasi berbasis IT } \\
\begin{array}{l}\text { Respon pengguna } \\
\text { terhadap Soal }\end{array}\end{array}$ & $93.42 \%$ & $6.57 \%$ \\
$\begin{array}{l}\text { Respon pengguna } \\
\text { terhadap Dosen pada } \\
\text { saat proses evaluasi }\end{array}$ & $93.42 \%$ & $6.57 \%$ \\
$\begin{array}{l}\text { Respon pengguna } \\
\text { terhadap } \\
\text { keberlanjutan } \\
\text { menggunakan alat } \\
\text { evaluasi berbasis IT } \\
\text { (Hot Potatoes) }\end{array}$ & $100 \%$ & $7.02 \%$ \\
Rata-Rata & & $0 \%$ \\
\hline
\end{tabular}

Berdasarkan Tabel 8 dapat disimpulkan bahwa hasil penilaian mahasiswa terhadap komponen produk yang sudah dikembangkan berada pada nilai yang positif, hal ini dikarenakan penilaian positif mahasiswa yang mencapai nilai > 80\%. Di samping itu mahasiswa memiliki minat yang tinggi untuk menggunakan alat evaluasi berbasis Hot Potatoes, hal ini ditunjukkan pada aspek respon pengguna terhadap keberlanjutan menggunakan alat evaluasi berbasis IT bahwasanya $100 \%$ mahasiswa berminat untuk menggunakan produk tersebut kembali. Dengan demikian, berdasarkan hasil penilaian mahasiswa yang bernilai positif (lebih besar dari 80\%), maka produk alat evaluasi ini bisa dikatakan praktis untuk digunakan.

\section{Analisis Data Keefektifan Instrumen}

Keefektifan instrumen tes evaluasi hasil belajar statistik yang dikemas dalam software hot potatoes yang dikembangkan diukur berdasarkan nilai hasil belajar mahasiswa baik secara individu maupun secara klasikal. Tes disusun berdasarkan kisi-kisi tes yang ada pada RPS. Hasil tes menunjukkan bahwa nilai rata-rata yang diperoleh mahasiswa yaitu 85,78 dan sebanyak 15 mahasiswa mencapai batas minimal ketuntatasan yang telah ditentukan dan empat mahasiswa belum memenuhi kriteria ketuntasan. Adapun persentase ketuntasan secara klasikalnya adalah 78,94 $\%$. Hal ini sudah dapat dikatakan instrumen tes yang dikembangkan efektif karena persentase ketuntasan klasikal telah melebihi $75 \%$.

Berdasarkan model pengembangan ADDIE dan uji-uji yang telah dilakukan baik itu uji validitas, kepraktisan, dan keefektifan. Dapat dinyatakan bahwasanya produk yang dikembangkan telah dinyatakan valid, praktis, dan efektif. Temuan ini sejalan dengan penelitian yang dilakukan oleh Yasa dkk (2020:26-32), yang juga mendapatkan hasil produk yang valid, praktis, dan efektif berupa $e$ evaluation menggunakan hot potatoes. Penilaian ini juga didasarkan pada hasil penilaian validator yang dinyatakan valid, Hasil penilaian pengguna yang memberikan respon positif, serta hasil belajar pengguna produk yang telah tuntas secara klasikal.

\section{Simpulan}

Produk instrument tes evaluasi hasil belajar statistik menggunakan software yang berbasis IT yaitu Hot Potatoes yang telah dikembangkan menggunakan model pengembangan 
ADDIE. Melalui kelima tahapan ADDIE diperoleh kesimpulan :

1. Produk dikatakan valid digunakan berdasarkan penilaian validator ahli materi dan ahli media dengan rata-rata hasil validasi ahli media sebesar 4,407 dan ahli materi sebesar 4,606.

2. Produk praktis untuk digunakan berdasarkan hasil penilaian positif mahasiswa yang rata-rata lebih dari $80 \%$ pada setiap aspek yang dinilai.

3. Produk juga efektif untuk digunakan berdasarkan Hasil tes mahasiswa menunjukkan persentase ketuntasan klasikal sebesar 78,94\%.

4. Setiap butir tes pada instrument tes evaluasi hasil belajar statistik berbasis Hot potatoes dinyatakan valid, reliable, dan sensitif.

Berdasarkan pedoman kriteria kelayakan, maka secara keseluruhan produk berupa instrument tes evaluasi hasil belajar statistik menggunakan software yang berbasis IT yaitu Hot Potatoes dinyatakan layak untuk digunakan.

\section{Daftar Pustaka}

Anggoro, S.D. \& Arif, M. (2018). The Effect of Using Hot Potatoes Application in Teaching Descriptive Text. Motoric (Media of Teaching Oriented and Children) Volume 2 No.1 Juni 2018

Arikunto, Suharsimi. (2011). DasarDasar Evaluasi Pendidikan. Jakarta : Bumi Aksara

Hobri. (2010). Metodologi Penelitian Pengembangan (Aplikasi Pada Penelitian Pendidikan Matematika). Jember : Pena Salsabila

Jabbarifar, T. (2009). The Importance of Classroom Assessment and
Evaluation in Educational System. Proceeding of the second International Conference of Teaching ang Learning INTI University College, Malaysia

Kasali, Renald. (2018). Disruption. Jakarta : PT Gramedia Pustaka Utama.

Mahirah B. (2017). Evaluasi Belajar Peserta Didik. Jurnal Idaarah 1 (2).

Pribadi, Benny A. (2009). Model Desain Sistem Pembelajaran. Jakarta: Dian Rakyat.

Rochmad. (2012). Model Pengembangan Perangkat Pembelajaran Matematika. Jurnal Kreano, Vol 3, No.1 Juni 2012

Saputri, D., Ashari, \& Kurniawan, E.S. (2015). Pengembangan CBT dengan Software Hot Potatoes pada Pembelajaran Fisika Dasar 2 di Universitas Muhammadiyah Purworejo. Jurnal Radiasi Vol 7 No. 2 September 2015

Setiana, D.S. (2018). Pengembangan Instrumen Tes Matematika untuk Mengukur Kemampuan Berpikir Kritis. Jurnal Pendidikan Surya Edukasi (JPSE) 4(2). 35-48.

Yasa, A. D., Suastika, K., \& Zubaidah, S.A.N. (2020). Pengembangan Evaluation Berbasis Aplikasi Hot Potatoes untuk Siswa Kelas V Sekolah Dasar. Jurnal Ilmiah Sekolah Dasar Volume 4 No. 12020. 26-32 